\title{
The Concreteness of Asymmetric War: Fragments of Experience
}

\author{
Giuseppe Caforio *
}

\section{Introduction}

Asymmetric warfare takes its name from the pitting of a weaker opponent against a stronger one, and from the use of war-fighting techniques that are vastly different from traditional military tactics. It is the use of these untraditional methods that enables the weaker side stand up to its stronger adversary. ${ }^{1}$ The radical difference of asymmetric warfare from what is now mostly referred to as conventional warfare lies both in the ethical aspect of the conflict and in the types of actions that typically take place, as well as in the instruments brought to bear and the strategies used.

The ethical aspect that characterizes asymmetric warfare is the disregard of any of the ethical standards governing warfare that prevail among most developed nations, replacing it with an ethic founded on religious and/or political fanaticism, disregard for human life, and the justification of every means of struggle that supports the desired end. The goals of the struggle never appear to be negotiable, and the general psychological condition of those engaged in such warfare can be summed up as "victory or death."

The concrete acts involved in asymmetric warfare serve to educate the younger generations in religious and/or nationalistic fanaticism up to and including martyrdom, with frequent recourse to suicide bombings, generalized bombing, armed attacks, targeted murders, kidnappings (even of persons unrelated to the conflict, for ransom), and the intimidation of populations. The tools used cover an extremely wide range: from traditional weaponry to explosives and chemical weapons to all the means of psychological warfare, propaganda, and indoctrination offered by the information and communications technologies of the Internet society, to the so-called shadow economy. The general strategy of a weaker adversary in an asymmetric campaign is to extend the war to the terri-

\footnotetext{
Giuseppe Caforio is retired general of the Italian Army. He is past president of the Research Committee 01 "Armed Forces and Conflict Resolution" of the International Sociological Association (for 12 years), vice-president of the Italian Interuniversity Centre of Historical and Military Studies, founding member and coordinator of a working group of the ERGOMAS, as well as member of several other institutes of research. He is also an outside consultant of the governmental Italian Centre of Strategic and Military Studies. He has a Strategic Sciences degree, a Law degree, a Political Science degree, and a Master in Communication Science.

1 In this kind of conflict, strong actors typically have a lower interest in winning asymmetric conflicts, because their survival is not immediately at stake. This lower interest level, in turn, often translates to higher political vulnerability, i.e., impatient, war-weary publics or self-interested elites might force their leaders to stop the conflict short of its initial objectives/war aims. Abandoned fights, finally, often translate to political defeats, especially when a weaker opponent does not need to win a fight, but merely survive it. In this way, asymmetry often gives an advantage to the weaker side.
} 
tory of the stronger side (typically an industrialized country). These states, in a centuries-long evolution, had succeeded in shifting such conflicts away from their cities and countryside to the boundaries of their world and beyond.

\section{The Practice of Asymmetric Warfare}

That this form of conflict can be legitimately included in the 'war' category seems to be demonstrated by statistical data: between January 1990 and March 2012, worldwide terrorist attacks caused 8,254 deaths and 12,576 wounded, with an increase in losses between the 1990 s and the first decade of the twenty-first century of 560 percent. $^{2}$ All this carnage took place during a period that historians and political scientists have considered a period of peace for the industrialized countries (if exceptions are made for the out-of-area small wars in Afghanistan and Iraq). A useful comparison in this regard is that in the Second Gulf War in Iraq, the coalition's human losses were a total of 4,836 deaths - that is, just slightly over half of those produced by twenty years of asymmetric conflict involving non-state actors.

It should also be pointed out that asymmetric conflict does not consist solely of the clash between fundamentalist Islam, represented by Al Qaeda, and the industrialized countries - "Jews, crusaders, and their apostate puppet regimes in the Islamic world," in typical Islamist parlance — as one can at times be led to think due to its strong public impact. Many other movements, both national and international, now adopt this form of struggle, as testified by the impressive list assembled by Gabriel Weimann:

- From the Middle East, Hamas (the Islamic Resistance Movement), the Lebanese Hezbollah (Party of God), the Al Aqsa Martyrs Brigades, Fatah Tanzim, the Popular Front for the Liberation of Palestine (PFLP), the Palestinian Islamic Jihad, the Kahane Lives movement, the People's Mujahedin of Iran (PMOI-Mujahedin-e Khalq), the Kurdish Workers' Party (PKK), and the Turkish-based Popular Democratic Liberation Front Party (DHKP/C) and Great East Islamic Raiders Front (IBDA-C).

- From Europe, the Basque ETA movement, Armata Corsa (the Corsican Army), and the Irish Republican Army (IRA).

- $\quad$ From Latin America, Peru's Tupak-Amaru (MRTA) and Shining Path (Sendero Luminoso), the Colombian National Liberation Army (ELN-Colombia), and the Armed Revolutionary Forces of Colombia (FARC).

- From Asia, Al Qaeda, the Japanese Supreme Truth (Aum Shinrikyo), Ansar al Islam (Supporters of Islam) in Iraq, the Japanese Red Army (JRA), Hizb-ul Mujehideen in Kashmir, the Liberation Tigers of Tamil Eelam (LTTE), the Islamic Movement of Uzbekistan (IMU), the Moro Islamic Liberation Front

2 Data taken from Wikipedia. 
(MILF) in the Philippines, the Pakistan-based Lashkar-e-Taiba, and the rebel movement in Chechnya. ${ }^{3}$

Although Islamic fundamentalism currently seems to be the main actor in the area of asymmetric warfare, this must not lead to the erroneous conclusion that it is the religion of Islam as a whole that provides the religious and ideological support for this form of struggle. Deep divisions exist in the Islamic world between 'moderate' Islamism, which propounds peaceful coexistence among peoples and strongly condemns the recourse to terrorism, and a radical, fundamentalist Islamism that advocates sharia law, pursues the objective of a global caliphate, and justifies any violent action carried out for that purpose under the banner of jihad). An example of the attitude of moderate Islam towards the tools and aims of fundamentalist Muslims can be seen in a petition recently disseminated on the Internet by an Islamic website, in which the "undersigned members of the peace loving and moderate majority of Muslims, revolted and repulsed by blasphemous bloodshed in Allah's name, reject as un-Islamic conduct all acts of terrorism ... in all its forms, bombings, shootings, knifings, hijackings, abductions and mass casualty attacks because they do unjust injury to innocent people and irreparable damage to Islam." The petition went on to call for the exclusion of any pro-terrorist rhetoric from Muslim schools and media, "withholding zakat from all organizations which teach, incite, facilitate or organize \& perform acts of terrorism," and for the entire Muslim community to reject the religious edicts that terrorist groups have used to justify their actions. ${ }^{4}$

In the light of this petition, and other statements by more moderate Muslims, Andrew Pratt's observation is instructive:

Today, Islam is not the only source of religious terror.... Religious terrorism descends from other religious communities as well. One needs only to walk through the mural-covered Catholic neighborhood of Bogside in Londonderry where violence between Catholic and Protestants has proven difficult to eradicate to appreciate a Christian contribution to religious terrorism. ${ }^{5}$

Furthermore, in order to more precisely define the weak-side actors in asymmetric warfare, it is useful to turn to Mary Kaldor's general definition of the new phenomena that characterize such conflicts, which she has referred to as "New Wars":

A typical new phenomenon is armed networks of non-state and state actors. They include: paramilitary groups organised around a charismatic leader, warlords who control particular areas, terrorist cells, fanatic volunteers like the Mujahideen, organised criminal

3 See Gabriel Weimann, "How Modern Terrorism Uses the Internet," Journal of International Security Affairs 8 (Spring 2005): 1-5; available at http://www.securityaffairs.org/issues/2005/ 08/weimann.php.

4 The full text of the petition, along with a list of specific acts that the signers reject as in opposition to Islam, can be seen at http://www.petitiononline.com/No2Jihad/petition.html.

5 Andrew Nichols Pratt, "Terrorism's Evolution: Yesterday, Today, and Forever," Connections: The Quaterly Journal 10:2 (Spring 2011): 1-33, quote on p. 19. 
groups, units of regular forces or other security services, as well as mercenaries and private military companies. ${ }^{6}$

The purpose of this article is to examine these aspects of asymmetric war in the context of specific episodes of their implementation, examining them as cases of unique historical experience.

\section{Ethical/Ideological Aspects}

The ideology of the movements that engage in asymmetric warfare tends to be global and totalizing. For the weaker parties in the world of radical Islamism - which today are most likely (although not exclusively) to use these techniques - the primary aspiration is to create a global caliphate by means of holy war and impose sharia everywhere. In a 2006 interview given shortly before his death, Al Qaeda leader Abu Musab al-Zarqawi explained the jihadists' goal thusly:

Our political agenda, ... is that of the saying of the Prophet (peace be upon him), I have been sent with the sword, between the hands of the hour, until Allah is worshipped alone ... this is what determines our political goal. We fight in the way of Allah, until the law of Allah is implemented, and the first step is to expel the enemy, then establish the Islamic state, then we set forth to conquer the lands of Muslims to return them back to us, then after that, we fight the kuffar (unbelievers) until they accept one of the three. I have been sent with the sword, between the hands of the hour; this is our political agenda. ${ }^{7}$

This aspiration is also echoed locally. For example, in a May 2010 statement titled "Who are the mujahideen in the Arabian Peninsula?," the group Al Qaeda in the Arabian Peninsula (AQAP) laid out its objectives as including the "expulsion of Jews and crusaders" from the Arabian Peninsula, the return of the Islamic caliphate, and the introduction of sharia law. ${ }^{8}$ Egypt has also seen similar calls:

On 25 April, the Ibn Taymiyyah media centre released a video showing a convoy of militant Islamist sympathisers, flying flags commonly associated with transnational jihadism, in the town of Al-Sheikh Zuweid in the Sinai Peninsula on 19 April. The video featured a man, identified as Sheikh Abu al-Bara, preaching about the importance of conducting jihad, who said: "Jihad is a duty even if it is only to free an inch of Muslim land; therefore personal jihad is the first of our obligations." 9

6 Mary Kaldor, New and Old Wars: Organized Violence in a Globalized Era (London: Polity Press, 2001), 9.

7 "Dialogue with Abu Musab Al-Zarqawi," interview with Al Qaeda media arm, 2006; available at http://www.kavkazcenter.com/eng/content/2006/12/20/6921_print.html.

8 “Al Qaeda in the Arabian Peninsula," Jane's World Insurgency and Terrorism (5 April 2012); available at http://articles.janes.com/articles/Janes-World-Insurgency-and-Terrorism/Al-Qaedain-the-Arabian-Peninsula-AQAP-International.html.

9 "OSINT Summary: Militant Islamists in Egypt's Sinai Call for Support of Syria Jihad," Jane's Terrorism and Security Monitor (1 May 2012); available at http://articles.janes.com/articles/ Janes-Terrorism-And-Security-Monitor-2012/OSINT-Summary-Militant-Islamists-in-Egypt-sSinai-call-for-support-of-Syria-jihad.html. 
Among radical Islamists, any tolerance towards other ideologies or religions (and every resulting possibility of compromise and settlement) is prohibited in these asymmetrical conflicts. Thus, a Muslim cleric named Abdul Nacer Benbrika (also known as Abu Bakr), in a 2005 interview in Australia, stated: "I am telling you that my religion [Islam] doesn't tolerate other religions. It doesn't tolerate. The only one law which needs to be spread, it can be here or anywhere else, has to be Islam." 10

The absence of ethical rules (even within Islam) for the conduct of asymmetric warfare by a weaker party is expressly declared by the leader of the movement that has to date most successfully waged such war, Al Qaeda: "In today's wars, there are no morals. We believe the worst thieves in the world today and the worst terrorists are the Americans. We do not have to differentiate between military or civilian. As far as we are concerned, they are all targets." ${ }^{11}$ Bin Laden extolled the physical destruction of his adversary without mincing words. Regarding the suicide bombing of the U.S. Navy destroyer USS Cole in Yemen, speaking at his son's wedding in southern Kandahar bin Laden said, "The pieces of the bodies of infidels were flying like dust particles. If you would have seen it with your own eyes, you would have been very pleased, and your heart would have been filled with joy." 12 According to bin Laden's version of Islam, asymmetric warfare waged under the banner of jihad is virtually a requirement of the faith, with very specific rewards: "It is far better for anyone to kill a single American soldier than to squander his efforts on other activities." 13 And, "In our religion, there is a special place in the hereafter for those who participate in jihad." 14

In such an ethical system, the sacrifice of one's life for the cause is part of a kind of "death culture," which accounts for the high number of suicide bombers that the movements that resort to forms of asymmetric warfare are able to have at their disposal. ${ }^{15}$ As Yunis al-Astal, a prominent Hamas leader stated, "The most exalted form of jihad is fighting for the sake of Allah, which means sacrificing one's soul by fighting the ene-

10 Michelle Grattan, "I Must Preach Holy War, Says Teacher," The Age (Australia) (5 August 2005); available at www.theage.com.au/articles/2005/08/04/1123125857077.html? from=top5.

11 Osama bin Laden, interviewed on "Nightline," $A B C$ News (10 June 1998); available at http://abcnews.go.com/2020/video/osama-bin-laden-interview-1998-13506629.

12 Quoted at his son's wedding in Kandahar. "Osama bin Laden," Wikiquote; available at http://en.wikiquote.org/wiki/Osama_bin_Laden.

13 Interview with Osama bin Laden, "Frontline," PBS (May 1998); available at www.pbs.org/ wgbh/pages/frontline/shows/binladen/who/interview.html.

14 Scott Macleod, "Osama bin Laden: The Paladin of Jihad," Time Magazine (6 May 1996); available at http://www.time.com/time/magazine/article/0,9171,984493,00.html.

15 As I have written elsewhere, "Today, the weak side's offensive tool is man, and man is often no longer a person who carries and operates a weapon but is himself a weapon who sacrifices himself to strike the adversary, and he does this because his mind has been convinced to do it." Giuseppe Caforio, "The Asymmetric Warfare: In Search of a Symmetry," in Armed Forces and Conflict Resolution: Sociological Perspectives, ed. Giuseppe Caforio, Gerhard Kümmel, and Bandara Purkayastha (Bingley, U.K.: Emerald Group Publishing, 2008), 7-24. 
mies head-on, even if it leads to martyrdom." ${ }^{16}$ Hassan Nasrallah, the secretary-general of Hezbollah, articulated similar radical Islamist sentiments in 2004 regarding the value of martyrdom: "We have discovered how to hit the Jews where they are the most vulnerable. The Jews love life, so that is what we shall take away from them. We are going to win, because they love life and we love death." 17 According to this view of asymmetric conflict, every person belonging to the stronger side is a legitimate target for acts of terrorism, regardless of their gender, occupation, etc. In a televised panel discussion on 19 October 2004 on the topic "What is a terrorist?," Mohamed Elmasry, the head of the Canadian Islamic Congress, declared that any Israeli over eighteen years of age is a valid target for Palestinian terrorist attacks: "Anybody above eighteen is part of the army." 18

Part of the rhetorical sleight-of-hand involved in these calls for jihad is to encourage Muslims to martyr themselves while simultaneously making one's own side out to be a subject of threat by the enemy (an old trick from ideological propaganda in conventional conflicts). As bin Laden stated when he called for a jihad against "Jews and Crusaders" in 1998, "To kill the Americans and their allies - civilians and military - is an individual duty for every Muslim who can do it in any country in which it is possible to do it, in order to liberate the Al-Aqsa Mosque [Jerusalem] and the holy mosque [Mecca] from their grip, and in order for their armies to move out of all the lands of Islam, defeated and unable to threaten any Muslim." ${ }^{19}$ This narrative holds that violent jihad is necessary to defend Islam and Muslim lands against an existential threat posed by Western militaries and the puppet regimes in the Muslim world that receive their support.

The Liberation Tigers of Tamil Eelam (LTTE), the Sri Lankan separatist group, is often credited with pioneering the use of suicide bombing as a terrorist tactic. In constructing their ideology, they took care to incorporate elements that would help in motivating suicide bombers and justifying massacres. As a Swedish anthropologist and expert on LTTE martyr culture argues:

Tamil politicians have used religious-Zionistic-terms to describe the commitment to the creation of a Tamil nation. This use of religious terms is, of course, not uncommon in a global perspective. Politicians have often talked about 'sacrifices' to be made for the nation. These religious terms should then not be squeezed too much; they are part of a political rhetoric. In the case of the LTTE, however, we find a whole set of technical reli-

16 "Palestinian Official: Women Must Martyr Themselves," WND.com (22 June 2007); available at http://www.wnd.com/2007/06/42195/.

17 Richard Landes, "What Gilad Shalit Tells Us about the Respect for Life in Europe, Israel, and Palestine," The Telegraph (U.K.) (21 October 2011); available at http://www.telegraph.co.uk/ comment/personal-view/8841737/What-Gilad-Shalit-tells-us-about-the-respect-for-life-inEurope-Israel-and-Palestine.html.

18 Quoted in "Muslim Leaders' Statements Affirm National Post's Position," HonestReportingCanada (27 October 2004); available at http://www.honestreporting.ca/news_article_name/ 765432antiarab.aspx.

19 Osama bin Laden, "Jihad Against Jews and Crusaders: World Islamic Front Statement," 23 February 1998; available at http://www.fas.org/irp/world/para/docs/980223-fatwa.htm. 
gious terms, a kind of repertoire that has been created after systematic search by members of the Office of Great Heroes of the LTTE. There is actually a special office in a house in Yalppanam dedicated to the task of producing hero symbolism and concepts. These are part of building up an ideological resistance and mobilization - alongside the building up of a military resistance... The LTTE provides a vision of cutantiram, "independence," of a projected state known as Tamililam, and that cutantiram is a "holy" aim, the Zion of the LTTE. That vision is the very centre of the LTTE as a political movement with religious aspirations. ${ }^{20}$

Another political actor in the field of asymmetric warfare who created its own peculiar ideology was the Japanese Aum Shinrikyo movement. In fact, as Andrew Pratt states, "The Aum Shinrikyo cult, which has been renamed Aleph, represented the most lethal manifestation of a New Age apocalyptic religious sect. Aum combined tenets from Buddhism, Hinduism, and Christianity and was obsessed by the apocalypse.... The group made headlines around the world when, on 20 March 1995, its members carried out a chemical attack in the Tokyo subway system." 21

\section{Concrete Acts}

Muslims must educate their children to Jihad and to hatred of the Jews, the Christians, and the infidels.

Saudi preacher Sheikh Muhammad Saleh Al-Munajjid ${ }^{22}$

The point of departure for every form of ideological fundamentalism is the education and indoctrination of the young. Islamic fundamentalism, for example, has achieved this process through the Islamic religious schools, or madrassas, which are in many contexts the only opportunity available to young people to acquire some sort of cultural education. $^{23}$

These schools have multiplied exponentially over the years. Data on Pakistan report that in 1947 there were 137 madrassas in the entire country, a number that had ballooned in 1994 to over 2,500 in Punjab province alone. In 2002, "Pakistan's minister for religious affairs, Dr. Mahmood Ahmed Ghazi, puts the figure at 10,000, though he acknowledges the problem of definition and suspects it could be higher, with as many as

20 Peter Schalk, "Historization of the Martial Ideology of the Liberation Tigers of Tamil Eelam (LTTE)," South Asia: Journal of South Asian Studies 20 (1997): 1-38.

21 Pratt, "Terrorism's Evolution," 25.

22 "Saudi Education System Majors in Jihad," WND.com (24 December 2002); available at www.wnd.com/2002/12/16394/.

23 "The Madrassas are Koranic schools that provide free religious education, boarding, and lodging and are essentially schools for the poor. About a third of all children who are in education in Pakistan attend Madrassa. Most of the students are between 5 and 18. The objective of the Madrassa is to introduce Muslim children to basic Koranic teachings, promote an Islamic ethos in society and groom students for religious duties. Enemy number one is secular education and the religious who control the Madrassa have always successfully opposed the government's various attempts to reform them." See CeMiSS Quarterly 3:2 (Summer 2005). 
one million to 1.7 million students attending classes at least for short periods." ${ }^{24}$ From the late seventies on, these Quranic schools, which have multiplied in the tribal areas bordering with Afghanistan, have produced a large reserve of young jihadist volunteers, determining factors behind Islamic radicalism in Pakistan.

The activity of many madrassas of educating their students in fundamentalism and jihad is attested by numerous examples. For example, a 2012 raid on the Jamia Darul Uloom Islamia madrassa in Jatoi, Pakistan "resulted in the recovery of 10 bags of explosives, each with a $50 \mathrm{~kg}$ capacity.",25

The ideological training given to the youths in the madrassas is accompanied by propaganda and political-religious indoctrination of the masses, which the weaker side in an asymmetric conflict accomplishes by exploiting all the communication tools that their adversary, the strong side, has developed in building the information society. ${ }^{26}$ Examples of this activity can be found in the creation of publications like the Englishlanguage magazine Inspire, aimed at co-religionists residing in strong-side countries, which encourages its readers to carry out attacks in their home countries. Islamist groups have also made use of the communication opportunities offered by the Internet, setting up websites like Al-Neda (The Call, shut down in 2002), which was established as Al Qaeda's principal online clearinghouse for ideological treatises and announcements and was administered from Saudi Arabia by Osama bin Laden loyalist Yusuf al-Ayiri. They have also based media outlets in the West, such as blogs for the purpose of propaganda and proselytism, as documented by the Italian newspaper Il Sole 24 Ore, which writes:

The Public Prosecutor's office of Cagliari has ordered that access be blocked to sites allegedly used to foment Islamic terrorism. The measure, which Il Sole 24 Ore was able to read, shuts down the sites:

blog.libero.it/islamnuri, blog.libero.it/islamitalia, ummusama.wordpress.com,

islamo-il-monoteismo.over-blog.com and abulbarakat.wordpress.com. ...

According to the Cagliari General Investigations and Special Operations Police, the investigated persons, "members of an Islamic fundamentalist group," used the sites to disseminate "religious propaganda material inciting to acts of violence" and "information and documents on learning war techniques for terrorist purposes," such as the "preparation or use of explosives, firearms and other weapons." 27

This exploitation of the Web has led Jane's to write, "There is growing concern that the Internet has replaced the Afghan training camps as the principal training ground for

24 Ibid.

25 "Counter-terrorism: SSP-linked Madrassa Raided by Agencies," The Express Tribune (Pakistan) (22 March 2012); available at http://tribune.com.pk/story/353428/counter-terrorism-ssplinked-madrassa-raided-by-agencies/.

${ }^{26}$ In asymmetric warfare, the primary use of communication and, especially, of the new information and communication technologies transfers an essential part of the military confrontation from the traditional "battlefield" to a media confrontation.

27 Il Sole 24 Ore (24 April 2012). 
aspirant jihadists. A vast library of information on bomb-making, weaponry and tactics is now available online." 28

Ideological training and indoctrination began producing results as early as 1983, the year in which the first major suicide terror attacks took place, including:

- 18 April 1983, Beirut, Lebanon: U.S. Embassy destroyed in a suicide car-bomb attack; sixty-three dead, including seventeen Americans. The group Islamic Jihad claimed responsibility.

- 23 October 1983, Beirut, Lebanon: Shiite suicide bombers exploded a truck near U.S. military barracks at Beirut airport, killing 241 marines. Minutes later a second bomb killed 58 French paratroopers in their barracks in West Beirut.

- 12 December 1983, Kuwait City, Kuwait: Shiite truck bombers attacked the U.S. Embassy and other targets, killing five and injuring eighty.

Terrorist attacks with explosive devices, often carried and detonated by militants willing to commit suicide, became even more frequent in the following years, and extended to much more vulnerable targets such as airliners. Here we recall the attack on 21 December 1988 over Lockerbie, Scotland, where a New York-bound Pan Am Boeing 747 exploded in flight from a terrorist bomb and crashed into the Scottish village, killing all 259 aboard and 11 on the ground. Passengers included 35 Syracuse University students and many U.S. military personnel. Libya formally admitted responsibility fifteen years later (August 2003) and offered USD 2.7 billion in compensation to victims' families.

The use of suicide bombers later extended also to ships, as occurred on 12 October 2000, when Al Qaeda operatives in Yemen carried out a suicide attack with an explosives-laden boat, causing significant damage to the U.S. Navy destroyer USS Cole and killing seventeen sailors. Or, before that, in the attack of 7 October 1994 in the Mediterranean Sea, when gunmen linked to Libya attacked the Italian cruise ship Achille Lauro, killing one U.S. tourist.

28 "Finding Nemo: Profile," Jane's Terrorism and Security Monitor (4 July 2008); available at http://articles.janes.com/articles/Janes-Terrorism-And-Security-Monitor-2008/Finding-

Nemo.html. Matt Armstrong, writing with reference to the Afghan theater of operations, provides an interesting example of the tools used locally in the fight by the weak side in this asymmetric warfare: "A website in the name of the former regime - the Islamic Emirate of Afghanistan - is used as an international distribution centre for leadership statements and inflated tales of battlefield exploits. While fairly rudimentary, this is not a small effort; updates appear several times a day in five languages. Magazines put out by the movement or its supporters provide a further source of information on leadership structures and issues considered to be of importance. But for the largely rural and illiterate population, great efforts are also put into conveying preaching and battle reports via DVDs, audio cassettes, shabnamah ("night letters," pamphlets or leaflets usually containing threats) and traditional nationalist songs and poems. The Taliban also increasingly uses mobile phones to spread its message." A mature use of 'globalization' processes seems evident here. Matt Armstrong, "The Art of Asymmetric Warfare," MountainRunner.us (28 July 2008). 
The use of suicide bombers was and is rather widespread from the weaker side of asymmetric conflicts everywhere. To give a concrete idea of the nature of these attacks, the passage below describes one suicide bombing carried out by the innovators of the method, the LTTE in Sri Lanka:

The Central Bank bombing was one of the deadliest terrorist attacks carried out by the LTTE during the Separatist civil war in Sri Lanka between the government and the Tamil Tigers. The attack took place on January 31, 1996, Sri Lankan city of Colombo. A lorry (42-6452) containing about 440 pounds of high explosives crashed through the main gate of the Central Bank, a seaside high-rise which managed most of the financial business of the country. As gunmen traded fire with security guards, the suicide bomber in the lorry detonated the massive bomb, which tore through the bank and damaged eight other buildings nearby. The lorry was followed by a three-wheeler, carrying two LTTE cadres armed with automatic rifles and an RPG launcher.

The blast killed at least 91 people and injured 1,400 others. At least 100 people lost their eyesight. Among the wounded were two U.S. citizens, six Japanese, and one Dutch national. Most of these were bystanders or civilians manning small shops set up near the bank. $^{29}$

But the escalation of terror continued, and culminated in the use of hijacked aircraft as weapons of mass destruction. As everybody knows, on 11 September 2001, Al Qaeda hijackers crashed two commercial jets into the Twin Towers of the World Trade Center in New York City; two more hijacked jets were crashed into the Pentagon in Arlington, VA, and a field in rural Pennsylvania near the town of Shanksville. Total dead and missing numbered 2,992: 2,749 in New York City, 184 at the Pentagon, 40 in Pennsylvania, and 19 hijackers. The Tamil Tigers attempted to follow this model with a suicide air raid on military locations in and around Colombo on 20 February 2009. These attacks failed, however, as the Sri Lankan Air Force was able to shoot down the explosive-laden planes before they reached their targets.

With these acts the strategy of taking the war inside the territorial borders of the stronger side is fully achieved, and is reconfirmed in significant later acts, such as the terrorist attacks on civilian targets carried out in Bali on 12 December 2002, in Moscow on 23 October 2002, in Madrid on 11 March 2004, in Beslan on 1 September 2004, in London in July 2005, and in Mumbai on 26 November 2008. The targets in these attacks have been crowded places in strong-side countries (shopping malls, large hotels, railways, subways, discotheques, restaurants, schools), particularly vulnerable means of transport (planes and airports), tourist groups, embassies, United Nations sites, government offices, barracks and residential compounds, but also individuals, who are often chosen for their symbolic importance, both for kidnappings and assassinations.

Such was the case of Dutch film director Theo van Gogh, assassinated on 2 November 2004, as well as those of kidnappings aimed at ransom or prisoner exchange, which often end tragically, as occurred on 11-19 June 2004 in Riyadh, Saudi Arabia, when terrorists kidnapped and executed Paul Johnson, Jr., an American, killing two other Ameri-

29 “Central Bank bombing," Wikipedia.org; available at http://en.wikipedia.org/wiki/Central_ Bank_bombing. 
cans and a BBC cameraman in gun attacks. On 26 April 2010, an AQAP suicide bomber targeted the convoy of the British ambassador to Yemen in the capital, Sana'a. Two security officials and a civilian were wounded in the attack, but the ambassador was unhurt. And finally, in May 2012, a member of the Higher Peace Council in Afghanistan, Arsalan Rahmani Daulat was shot with a silenced pistol while on his way to work in Kabul. As was the case with suicide bombings, Islamist groups were again following the lead of the Tamil Tigers, who achieved perhaps their most spectacular success in political assassination on 21 May 1991, when LTTE gunmen assassinated former Indian prime minister Rajiv Gandhi in Tamil Nadu, then committed suicide after being surrounded by police. Kidnappings can also be carried out for propaganda purposes, as is the case with Westerners who have been kidnapped in Afghanistan and Pakistan by Islamist terrorists, who have circulated footage online of their hostages reading prepared statements denouncing Western policies.

The concrete acts of the weaker side in asymmetric conflicts are complemented by hot war and/or guerrilla actions where the conditions of the terrain and the political and social situation permit. The leading example here is Afghanistan, where from 2001 to 2011 the losses of the coalition forces (strong side) amounted to 2,765 dead.

\section{Instruments Used}

As has already been mentioned, the information and communication technologies made available by today's information society are instruments that the weaker side in asymmetric conflict has shown itself adept at turning to its advantage. ${ }^{30}$

First and foremost is the Web. As Gabriel Weimann writes:

By its very nature, the Internet is in many ways an ideal arena for activity by terrorist organizations. Most notably, it offers

- $\quad$ Easy access;

30 The communication technologies available today (especially information and communication technologies) have offered a new and quite vast range of instruments to these groups, enabling far-flung propaganda and information by means of the Internet; safe, widespread connections (mobile phones and email); and propaganda for training in guerrilla warfare and/or terrorism through the distribution of DVDs. See Giuseppe Caforio, "The Information Society and The Changing Face of War," in Society, Culture and Technology at the Dawn of the $21^{\text {st }}$ Century, eds. Janusz Mucha and Katarzyna Lesczczynska (Newcastle upon Tyne, U.K.: Cambridge Scholars Publishing, 2010), 129-42. And this happens because "Democracies offer the ideal basic conditions for terrorism.... In particular, the broadcast media and the Internet enable terrorists to thrive in a cancerous manner in the spaces created by the freedom that democracies provide - the very freedom that Islamist terrorists seek to abolish." "The increasing globalization of the media and satellite reporting," Bockstette goes on, "as well as the rapid development of the Internet have extended the scope of the terrorists' potential audience.... The symbiotic relationship between terror events and media is apparent; the perpetrators would have far less impact without media publicity, and the media can hardly be expected to resist reporting on terror events." Carsten Bockstette, "Taliban and Jihadist Terrorist Use of Strategic Communication," Connections: The Quarterly Journal 8:3 (Summer 2009): 13. 
- Little or no regulation, censorship, or other forms of government control;

- Potentially huge audiences spread throughout the world;

- Anonymity of communication;

- $\quad$ Fast flow of information;

- Inexpensive development and maintenance of a web presence;

- A multimedia environment (the ability to combine text, graphics, audio, and video and to allow users to download films, songs, books, posters, and so forth);

- The ability to shape coverage in the traditional mass media, which increasingly use the Internet as a source for stories. ${ }^{31}$

Added to this is the use of the traditional media, whose importance as a tool in the struggle appears to be very clear to the leaders of fundamentalist movements. As Ayman al-Zawahiri wrote in July 2005: "We are in a battle, and more than half of this battle is taking place in the battlefield of the media.... We are in a media battle for the hearts and minds of our Ummah." 32 Another Islamist magazine wrote: "Film everything; this is good advice for all mujahideen. ... You should be aware that every frame you take is as good as a missile fired at the Crusader enemy and his puppets." 33

We have an interesting local example of weak-side exploitation of the media reported by Jane's for the Arabian Peninsula:

The importance of effective propaganda has been recognised by Al Qaeda operatives in the region since the beginning of the campaign. In 2003 and 2004, the original AQAP in Saudi Arabia regularly published two online magazines: Muaskar al-Battar (Al-Battar Training Camp), which focused on targeting, tactics, and weapons; and Sawt al-Jihad (Voice of Jihad), which dealt more with ideological issues. These publications were supported by written statements that were posted on websites to claim responsibility for attacks and the occasional video.

AQAP began publishing an English-language magazine called "Inspire" in July 2010. The most recent, seventh issue was published in October 2011. Inspire attempts to incite grassroots jihadists living in Western countries. It does this by claiming that aspirant jihadists can play an important role in weakening the Western powers; promoting detained grassroots jihadists as heroes, even when their attempts to carry out attacks were highly amateurish; providing ideas for carrying out simple attacks such as using vehicles equipped with metal blades to mow down civilians; and instructions on how to make basic IEDs from readily available materials. Examples of individuals promoted by Inspire include Roshonara Choudhury, who stabbed and wounded a British parliamentarian in May 2010, and Taimour Abdulwahab al-Abdaly, the suicide bomber who killed only himself in Stockholm in December 2010. ${ }^{34}$

31 Weimann, "How Modern Terrorism Uses the Internet."

32 Craig Whitlock, "Keeping Al-Qaeda in His Grip: Al-Zawahiri Presses Ideology, Deepens Rifts Among Islamic Radicals," Washington Post (16 April 2006); available at www.washingtonpost.com/wp-dyn/content/article/2006/04/15/AR2006041501130_pf.html.

33 "Internet Jihad: A World Wide Web of Terror," The Economist (12 July 2007); available at http://www.economist.com/node/9472498.

34 "Al Qaeda in the Arabian Peninsula," Jane's World Insurgency and Terrorism (5 April 2012). 
The Tamil Tigers also developed their own system of communications and propaganda, going as far as to create their own satellite television network that was available across Asia and the Middle East. ${ }^{35}$

Extensive use is also made of television spots and attackers' declarations before suicide bombings, which manage to reach even the most remote villages beyond the range of television networks with special mobile units equipped with DVD players. It is interesting to note that, according to Jane's reports for the Arabian Peninsula, statements made by individual militants before blowing themselves up are not necessarily their own words, but rather are written in advance by media department personnel.

Another way to directly run the media is to create it yourself. Again, this can be a newspaper, a journal, or a radio station, but in some cases terrorists have created their own television channel as well, even broadcasting it over satellite to millions of homes throughout the world, as did the Tamil Tigers (see above). The best example is the Lebanese Hezbollah's Al-Manar satellite channel. Started in 1991, Al-Manar directly broadcasts Hezbollah's point of view, and does so very successfully. In fact it is said to be in the top five most-watched television channels in the Middle East, and internationally it has reported approximately ten million viewers per day. ${ }^{36}$

But before they create sophisticated media outlets, the first tools in terrorists' strategic arsenal are explosives, used in very diverse ways: from the suicide bomber, who wears explosive belts, to the more often used car or truck packed with TNT, to the explosive speedboat, to the parcel bomb sent by mail or loaded onto a cargo plane, to the IED placed alongside a road. There is no need to cite other examples of bombs or suicide bombers here, as numerous examples of them have already been given above. However, three more particular and perhaps less well-known cases are worth recalling:

- 1 September 1992, Saindamaradu, Kalmunai, Sri Lanka: An LTTE bomb fixed to a push-cycle carrying an ice-cream container exploded at a market, killing twenty-two people and injuring sixty-seven others.

- 29 October 2010: Two IEDs, sent from Yemen to Chicago using international courier companies, are intercepted in the United Kingdom and the United Arab Emirates. The devices were disguised as harmless toner cartridges in laser printers and addressed to synagogues in Chicago.

- 17 January 2011, Spokane, Washington: A pipe bomb is discovered along the route of the Martin Luther King, Jr. Day memorial march. The bomb, a "viable device" set up to spray marchers with shrapnel and to cause multiple casualties, is defused without any injuries.

35 Kasun Ubayasiri, "Velupillai Prabakaran, Leader of Tamil Eelam: An Elusive Leader's Annual Speech," paper published by Central Queensland University, 2006; available at http://tamilnation.co/ltte/vp/mahaveerar/06ubayasri.htm.

${ }^{36}$ See Avi Jorisch, Beacon of Hatred: Inside Hizballah's al-Manar Television (Washington, D.C.: Washington Institute for Near East Policy, 2004). 
Terrorists have shown themselves capable of adapting any form of explosive device to their ends, but they also do not shrink from the use of chemical weapons. The only reason the use of such weapons has remained limited is due to the difficulties involved in handling them. An example of a rare success in this regard took place Japan in 1995, when the religious cult Aum Shinrikyo released sarin gas in the Tokyo subway, killing thirteen people and injuring more than 5,000. This attack was the culmination of a series of eight attacks the terrorist group had executed in a twenty-month period.

The use of light weaponry is also frequent in terrorist actions, but such arms are likely to inflict more limited damage and are therefore less suitable for achieving the sought-after impact on public opinion. For these reasons they are not one of the favorite tools in the terrorist's arsenal, which contains a vast array of instruments of death and intimidation, ranging from knives to bulldozers. These and all the other instruments that human inventiveness can produce, in a framework free from moral constraints, have been and are being used by the weaker side in asymmetric conflicts.

In a context where there are no precise boundaries between asymmetric warfare and organized crime, arms and explosives smugglers have little trouble supplying the instruments of death to those who are able to pay for them. Antonio Maria Costa, Executive Director of the UN Office on Drugs and Crime, commented on this connection in November 2005:

I do not believe terrorism, even when politically motivated, can be separated from crime. ... While at the extremes these two activities differ, a grey area connects them. Violencebased intimidation is a traditional modus operandi for organised crime. Criminals sometimes wear the ideological mantle of terrorists, while many terrorists end up motivated more by greed than politics. In real life, fighting one evil is often equivalent to fighting the other. ${ }^{37}$

Terrorists' ability to pay is guaranteed through what has been called the shadow economy of terrorism. As I have written elsewhere:

A collateral phenomenon that several authors ... call "shadows of war" constitutes the economic support of the present forms of warfare, spanning the globe from urban to rural, across war and peace. The illicit trade in diamonds, timber, drugs, weapons, cars, labour, etc., shares the same shadows as the illegal and informal trade in prescription drugs, Asian software, food and clothing. ...

The new forms of warfare produce, in fact, a new kind of economy, based on violence. Money is collected through robberies, pillaging, drugs, spirits, cigarette trafficking, managing illegal immigration, forcing regular immigrants to give up a share of their wages, taxing international humanitarian assistance. According to some writers ... the new wars can be considered the main source of the global informal economy, i.e. of the transnational criminal economy, that represents the dark side of globalization. ${ }^{38}$

37 Jane's Intelligence Review (17 February 2006).

38 Giuseppe Caforio, "The Military Profession and Asymmetric Warfare," in New Wars, New Militaries, New Soldiers: Conflicts, the Armed Forces and the Soldierly Subject (Vol. 19 in Contributions to Conflict Management, Peace Economics and Development), ed. Gerhard 
The ideologization of the struggle adds other funding possibilities to these forms, which we might term "good faith" possibilities. For example, Jane's reports that:

AQAP has traditionally funded itself through two main mechanisms. The first is through zakat, or philanthropic religious donations to AQAP-connected collectors. The second is through mosque collections, though this has been regulated to some extent at larger mosques in Saudi Arabia. In both mechanisms, all transactions are in cash. Although some donors may know how their money is being used (so-called "armchair militancy"), the majority believe their donations are used by Islamic charities. ${ }^{39}$

And of course, the use of zakat to fund Islamic terrorist groups is not limited to the Arabian Peninsula. The purchase of weapons and explosives is facilitated by the arms bazaars that have sprung up far and wide since the end of the Cold War and the collapse of the Soviet Union. Much of the weaponry that can be purchased at these open-air arms markets comes from Russia and China, although some has also made its way from the Balkans to the Middle East.

\section{Strategies Adopted ${ }^{40}$}

The strategies used by the weaker side in asymmetric conflicts increasingly tend to be global. For example, it appears to be a constant on the part of the weaker side in asymmetric conflicts to try to isolate the principal adversary (in the current situation of the war on terror, the United States) from its allies. We are offered an interesting example of this strategy by a document published on a radical Islamist website, reported by Carsten Bockstette, which reads: "We think that the Spanish government could not tolerate more than two, maximum three blows, after which it will have to withdraw because of popular pressure. If its troops still remain in Iraq after those blows, then the victory of the Socialist Party is almost secured, and the withdrawal of the Spanish forces will be on its electoral program." ${ }^{\prime 11}$ As we know, that is what actually happened in Spain following the transit bombings in Madrid in 2004.

The communication must be global also. The leadership of the weak-side movements in fact demonstrates clear awareness of the importance of the media when developing their fighting strategies, as already illustrated in the section devoted to the instruments used. It is a struggle that rarely remains limited to the context of the region or state

Kümmel and Joseph Soeters (Bingley, U.K.: Emerald Group Publishing, 2012), 8-13. See also Mary Kaldor, New and Old Wars: Organized Violence in a Globalized Era (London: Polity Press, 2001); David Kilcullen, The Accidental Guerrilla: Fighting Small Wars in the Midst of a Big One (Oxford: Oxford University Press, 2009).

39 "Al Qaeda in the Arabian Peninsula."

40 It is a common experience to see new aspects of war in the twenty-first century. These new forms of warfare appear to be characterized by a predominantly political and ideological (often religious) nature, by a diligent effort to exploit the media, and by consciously and determinedly ignoring any ethical standard of war fighting. The strategy is to gain political power by sowing fear and hatred, to create a climate of terror, eliminate moderate voices and defeat tolerance (see Caforio, "The Asymmetric Warfare: In Search of a Symmetry").

Bockstette, "Taliban and Jihadist Terrorist Use of Strategic Communication," 7. 
where it arises, but most often is internationalized, through various instruments and procedures. For example, Turkish jihadists have increasingly resorted to the Internet to reach a global audience:

\begin{abstract}
Although Arabic remains the dominant language of jihadist internet activity, there has been a visible growth in the number of Turkish language radical Islamist websites and discussion forums in recent years. Most target jihadist sympathisers living in Turkey, although there are now also websites that appear to be primarily directed at ethnic Turks living in Western Europe, particularly the estimated three million Turkish speakers in Germany. ${ }^{42}$
\end{abstract}

AQAP's most significant alliance appears to be with the Somali group Al Shabab. Both organizations have released statements expressing support for each other, and some Yemeni jihadists are known to have fought in Somalia. Such statements often stress the importance of unity within the ummah (global Muslim community). ${ }^{43}$

That the recourse to asymmetric warfare techniques has become the instrument of choice of weaker parties, in whatever context they find themselves, is witnessed also by past and recent events from well beyond the Middle East. In 2008, Chinese government agents arrested members of two alleged terrorist groups in the Xinjiang Uighur Autonomous Region in western China on suspicion that the groups - made up of ethnic Turkic separatists-were planning to sabotage the Olympic Games in Beijing. ${ }^{44}$ In India, simultaneously with the rise in Islamist terrorism, a Maoist insurgency has been steadily expanding its scope and capabilities. The group has grown so significantly that in 2007 Indian Prime Minister Manmohan Singh described the Maoists as the "single biggest internal security challenge facing India." ${ }^{25}$ The uprising against the Assad regime in

42 “Turkish Jihadis Go Online," Jane's Terrorism and Security Monitor (26 March 2009).

43 "OSINT Summary: AQAP Reaches out to Affiliate Organisations in Africa," Jane's Terrorism and Security Monitor (24 May 2012).

44 "OSINT Update: China Rounds up 'Olympics Terrorism Conspirators'," Jane's Terrorism and Security Monitor (9 May 2018).

45 "Red Storm Rising: India's Intractable Maoist Insurgency," Jane's Intelligence Review (15 May 2008). Chas Morrison writes in this regard: "A long-standing left wing extremist (LWE) insurgency across India has led to the deaths, injuries or displacement of thousands of people, whilst being mostly overlooked by Western theorists. Many academic analyses dealing with revolutions, insurgencies, and civil war do not mention the Naxalites whatsoever. The Naxalite conflict would likely be more well-known if global attention were less focused on events across the border in Pakistan and Afghanistan, or if a number of foreigners had been killed. The insurgency started in the town of Naxalbari in West Bengal state, and thus the rebels are often known as 'Naxalites' (interchangeably with 'Maoists', 'extremists', 'rebels', or 'insurgents'). While all figures of the total number of combatants must be regarded as approximations, the BBC claims there are between 10,000 and 20,000 armed Naxalite cadres." Morrison, "Grievance, Mobilisation and State Response: An Examination of the Naxalite Insurgency in India," Cesran International (23 May 2012); available at http://cesran.org/index.php?option= com_content\&view=article\&id=1456\%3Agrievance-mobilisation-and-state-response-anexamination-of-the-naxalite-insurgency-in-india\&catid=65\%3 Amakale-ve-raporlar\&Itemid= 318\&lang=en. 
Syria in 2012 has also displayed some traits similar to those used by insurgent movements in Iraq and elsewhere, including the use of IEDs and truck bombs. In these cases we see that, when faced with the power of the state apparatus, even a revolutionary movement that is internal to a single state will resort to terrorism to carry forward its struggle.

The weaker side's strategies also include attempts to strike the economies of the countries where the struggle takes place, both by sabotaging industries, especially extractive ones, and by attacking tourism, which is often the main source of income for such countries. In the first type, Al Qaeda cells in Saudi Arabia have tended to focus on two primary targets: U.S. military units stationed in the country, and Westerners and other expatriates associated with the oil industry. Examples of the second type of attack include suicide bombings carried out against tourist groups in Yemen. On 2 July 2007, a suicide car bomb at the Queen of Sheba temple killed eight Spanish tourists and two Yemenis. On 15 March 2009, a suicide bomber killed four South Korean tourists and their Yemeni guide; this attack was followed up by another suicide bombing three days later targeting the initial victims' visiting relatives (using an IED that was concealed inside a portable stereo). ${ }^{46}$ These attacks come on top of other, better-known episodes like the tourist massacres committed in Egypt (at Luxor on 17 November 1997, where sixtytwo people were killed, and in the resort city of Sharm el-Sheikh on 23 July 2005, which killed eighty-eight people, mostly Egyptians).

The advanced technical capabilities required to carry out such attacks do not appear limited to a single theater or a single faction. For instance, according to Jane's, "Terrorists in Pakistan have developed the ability to remotely track and detonate vehicle bombs.... bombs could be planted in a vehicle without its owner knowing, tracked using GPS and mobile telephone systems, and then triggered with a text message when it reaches its target." ${ }^{47}$ Targets are struck all over the world, as is testified by news reports from New Delhi, India in 2012 that CCTV cameras had captured footage of a motorcyclist attaching a magnetic bomb to a car driven by the wife of an Israeli diplomat. ${ }^{48}$

Finally, the armed attacks have evolved according to increasingly sophisticated guerrilla strategies, as can be seen from AQAP commander Muhammad al-Awfi's statements in Saudi television interviews in early 2009. He said the organization would establish camps in Yemen's mountains from where it could send saraya (cells) into the Saudi kingdom to identify suitable targets, then return to Yemen to plan the attack and get the leadership's approval. If approved, the cell would return to carry out the attack, before withdrawing to Yemen, at which point another unit would rotate into the kingdom. According to al-Awfi, AQAP's strategists believed this campaign would humiliate the Saudi security forces, which would be unable to respond, as AQAP would have virtually no network in Saudi Arabia for them to dismantle.

\footnotetext{
46 "Al Qaeda in the Arabian Peninsula."

47 “OSINT Update: Pakistani Terrorists Deploy Tracked Car Bomb," Jane's Terrorism and Security Monitor (9 May 2008).

48 "Shadow War between Iran and Israel Escalates," Jane's Defence Weekly (17 February 2012).
} 
As can be seen, resorting to terrorism is only one of the forms of struggle of the weaker side in asymmetric conflicts, although it is perhaps the most widespread. Where they are able to do so, weaker-side groups will also launch deadly attacks of the conventional type or using guerrilla techniques. Mention has already been made of the attacks and ambushes carried out against the coalition forces in Afghanistan, which have been widely publicized in the media, but many other forms of attacks are carried out by insurgents in Afghanistan on the local level that do not garner coverage in the global media. Jessica Snapper captures this aspect of asymmetric warfare quite well, writing:

The beauty of irregular warfare is that while it employs indirect and asymmetric methods, it also utilizes a range of other advanced military capabilities that can erode the adversary's power and influence, despite conventionally superior technologies and infrastructure. In effect, irregular warfare is most potent in a protracted struggle, abrading the resolve of the enemy state and its strategic partners over time. ${ }^{49}$

AQAP, for example, demonstrated its continued ability to carry out mass-casualty attacks on 26 February 2012, when a suicide car-bomb attack in the city of Mukalla in Yemen killed twenty-six Republican Guard soldiers. ${ }^{50}$ A little over a week later, as many as 191 soldiers were killed and at least 73 others were kidnapped in a series of attacks by AQAP militants in and around the town of Zinjibar on 4 March. Two separate vehicle-borne IEDs were detonated on the outskirts of the city before a large force of militants assaulted and overran a military base several kilometers from the town. During the attack on the military base, AQAP militants seized a quantity of heavy weaponry, including a tank and several armored vehicles. ${ }^{51}$

\section{Conclusions}

Many theoretical works and studies exist on asymmetric warfare, but the goal of this essay is to bring the conversation back to its concrete development, evolution, and growth, as well as to provide an overall picture. ${ }^{52}$ I believe that only a thorough knowledge and understanding of its strategies, the instruments used, the diversity of the cases, and the ethical background can give a complete, global view of this phenomenon. Our mentality

49 Jessica Snapper, "Hezbollah Bolsters Irregular Warfare Capabilities,” JessicaSnapper.com (17 May 2012); available at http://jessicasnapper.com/2012/05/17/hezbollah-bolsters-irregularwarfare-capabilities/.

50 "Yemen Bomb Attack 'Kills at least 26 people' in Mukalla," BBC News (25 February 2012); available at www.bbc.co.uk/news/world-17164558.

51 Bill Roggio, “AQAP Overruns Yemeni Army Base, Kills 185 Soldiers,” Long War Journal (4 March 2012); available at http://www.longwarjournal.org/archives/2012/03/aqap_overruns_ yemeni.php.

52 See, among others, Yaakov Amidror, "Winning Counterinsurgency Wars: The Israeli Experience," JCPA Strategic Perspectives (June 2008); "The Asymmetric Warfare: In Search of a Symmetry"; "The Military Profession and Asymmetric Warfare"; Kilcullen, The Accidental Guerrilla; Frederick Teo Li-Wei, "Rethinking Western Vulnerabilities to Asymmetric Warfare," Journal of the Singapore Armed Forces 2 (2002); and John A. Nagl, Let's Win the Wars We're In (Washington, D.C.: Center for a New American Security, 2009). 
as citizens of developed, industrialized countries can make it difficult for us to follow the logic of a world where desperation, revanchism, and ideology come together to create ethical values (which we would consider anti-values) and behaviors that are so distant from our appreciation for life, our constant struggle to reduce the causes of death, our striving after well-being or, as the United States' Declaration of Independence put it, the "pursuit of happiness."

The very fact that these forms of struggle have been largely chosen and theorized in Eastern countries (both the Middle and Far East), where vertical thinking prevails over the horizontal (or linear, scientific, rational) thinking common in the West, makes it more difficult for us to follow their path and origins. ${ }^{53}$ The most advisable course thus seems to be to base oneself on the concrete facts, following Vico's axiom that "verum est ipsum factum" (truth itself is constructed). ${ }^{54}$

53 See Lucien Bruchon, who states with regard to Eastern thought: "Analogical-intuitive-reticular thinking does not deny the existence of horizontal causal chains but also evidences a vertical connection of similarity between systems that are only apparently unconnected. Analogy is actually vertical thinking that highlights the simultaneousness of phenomena that take place on different planes." Lucien Bruchon, "Pensiero logico-razionale-lineare e pensiero analogicointuitivo-reticolare," essay available at http://www.spiritualitaolistica.it/indice_libro_a.php.

54 Giambattista Vico, De Antiquissima Italorum Sapientia, 1710. See also James C. Morrison, "Vico's Principle of Verum is Factum and the Problem of Historicism," Journal of the History of Ideas 39:4 (October-December 1978): 579-95. 
THE QUARTERLY JOURNAL

\section{Bibliography}

Caforio, Giuseppe. "The Asymmetric Warfare: In Search of a Symmetry." In Armed Forces and Conflict Resolution: Sociological Perspectives. Bingley, U.K.: Emerald Group Publishing, 2008.

Kaldor, Mary. New and Old Wars: Organized Violence in a Globalized Era In London: Polity Pres., 2005.

Macleod, Scott. "Osama bin Laden: The Paladin of Jihad." Time Magazine (1996).

Morrison, James C.. "Vico’s Principle of Verum is Factum and the Problem of Historicism." Journal of the History of Ideas 39, no. 4 (1978): 579-95.

Pratt, Andrew Nichols. "Terrorism's Evolution: Yesterday, Today, and Forever." Connections: The Quarterly Journal 10, no. 2 (2011): 1-34.

Schalk, Peter. "Historization of the Martial Ideology of the Liberation Tigers of Tamil Eelam (LTTE)." South Asia: Journal of South Asian Studies 20 (1997): 1-38. 